\title{
EFFECT OF IRRIGATION WATER SALINITY AND TILLAGE SYSTEMS ON SOME PHYSICAL SOIL PROPERTIES
}

\author{
D. F. Hassan \\ ,Assis. Lecturer
}

Coll of Water Resources Engineering

\section{A. A. Jafaar}

Assis. Lecturer
R. J. Mohamm

Assis. Lecturer

Coll. of Agriculture
diaafliah87@gmail.com

\section{ABSTRACT}

The current study investigated the effect of water quality (the salinity of the irrigation water) and Tillage system on some soil physical properties. The experiment was carried out using RCBD with three replicates. wheat was irrigated by three water sources, a river ,dranege and well waters with electrical conductivities $1.3,3.5$ and $6.9 \mathrm{ds} . \mathrm{m}^{-1}$ respectively and three tillage systems were zero tillage (ZT), conventional tillage (CT) and deep tillage (DT). After harvest, some soil physical properties were evaluated including: bulk density, porosity, penetration resistance, hydraulic conductivity and mean weight diameter. The result showed that the bulk density values were $1.40,1.44$ and $1.47 \mathrm{mg}^{-3}{ }^{-3}$ for river, derange and well water. while the porosity values were $47.3 \%, 45.8 \%$ and $43.8 \%$. for river, derange and well water. while the hydraulic conductivity were $5.13,4.26$ and $4.36 \mathrm{~cm} \cdot \mathrm{h}^{-1}$ for river, derange and well water. also the result showed that the bulk density values were $1.48,1.44$ and $1.38 \mathrm{mg}^{-3} \mathrm{~m}^{-3}$ for $\mathrm{ZT}$, CT and DT respectively. while the porosity values were $44.3,45.7$ and $47.8 \%$ for ZT, CT and DT respectively. But for the interactions for electrical conductivity with tillage The result showed that the bulk density values were $1.50 \mathrm{mg} . \mathrm{m}^{-3}$ for well water with ZT but decrees value it become $1.34 \mathrm{mg} \cdot \mathrm{m}^{-3}$ for river water with DT. The best type of tillage was conventional tillage as it has the ability to improve properties of soil as well as it helps to reduce.

Key words: bulk density, porosity, zero tillage, conventional tillage, well water, drainage water

حسن وآخرون مجلة العلوم الزراعية العراقية -2019 :50 (عدد خاص):42:

$$
\begin{aligned}
& \text { تأثير ملوحة مياه الري ونظم الحراثة في بعض صفات التربة الفيزيائية }
\end{aligned}
$$

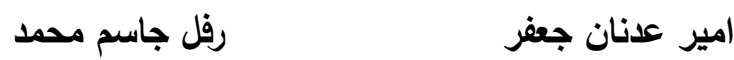

$$
\begin{aligned}
& \text { مدرس مساعد مدرس مساعد } \\
& \text { كليــــة الزراعــــــة /جامعة القاسم الخضراء }
\end{aligned}
$$

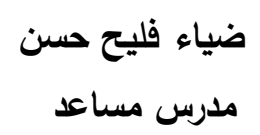

المستخلص - (الم

تهاف الدراسه الحالية الى بيان مدى تاثير نوعية المياه (ملوحة مياه الري) ونظم الحراثة على بعض الصفات الفيزيائية للتربة. تم تنفيذ التجربة باستخدام

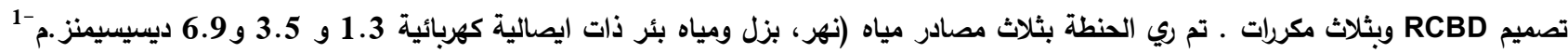

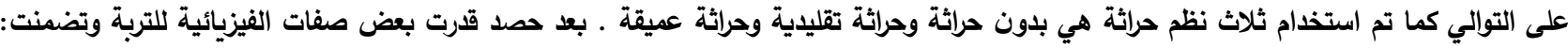

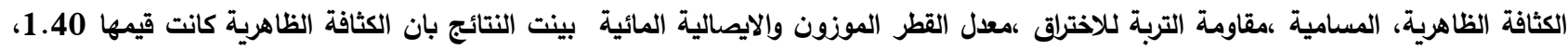

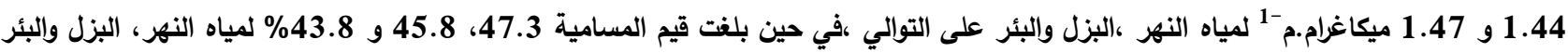

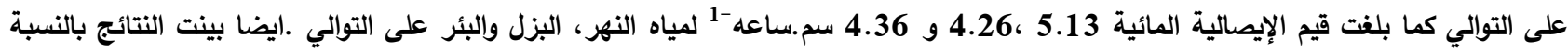

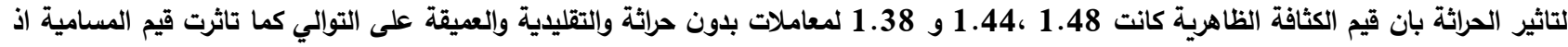

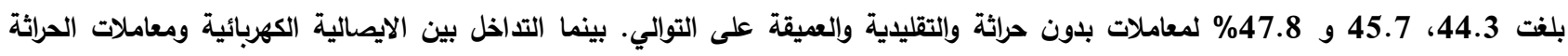

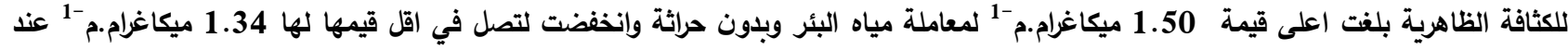

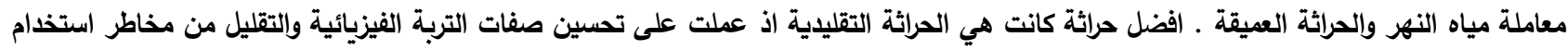
المياه المالحة. 


\section{INTRODUCTION}

The lack of water such as river water leads to increase the demands of water for irrigation purposes. From this point, the need to find alternatives to water as salty water represented by wells water and used them in agriculture. One should take in account the availability of a good management to the water and soil by using as reduces surface cover with salty water irrigation to reduce the dangerous effects and using modern irrigation techniques (9) . It becomes necessary to exploit the subsurface water since the Arab World has a subsurface reserve around 14.3 thousand billion cubic meters (8). The investment of this reserve is low because its renewal rate is very low about $0.3 \%$. One of the major problems in exploiting water resources is the increase of salinity. The most important way to develop and organize water use is to exploit salty water by reducing its poison effect. When using three different types of water to sate their effect on some physical properties of soil, particularly permeability (12) found that the increase of irrigation water salinity leads to increase bulk density and to decrease mean weight diameter. (16) points out that using $10-100 \mathrm{~mm} . \mathrm{L}^{-1}$ reduces electrical conductivity of soil because of clay expansion. One of the best means which results in a good management to the soil and exploiting it ideally is the tillage practice (10). Deep tillage reduces bulk density and increases mean weight diameter and hydraulic conductivity (22) . (23 , 5)found that conventional tillage leads to decrease bulk density and gives rise to soil porosity. (4) used four types of tillage: zero tillage (ZT), minimum tillage (MT), conventional tillage (CT) and deep tillage (DT). they found that the highest value of bulk density was at zero tillage (ZT) and lowest was at deep tillage (DT), and the reverse was for the porosity. in his study to three types of tillage at different depths 0,20 and $30 \mathrm{~cm},(11)$ found that penetration resistance was $1142.8 \mathrm{kpa}$ without tillage, but this value was decreased along with the tillage depths. He refers to the fact that soil physical properties were not appropriate without tillage. On the contrary, the soil physical properties were more appropriate at
$20 \mathrm{~cm}$ depth (1). To compare deep tillage to conventional tillage, the former got the following properties: lower penetration resistance, lower soil bulk density and higher root length density on loam soil across depths (15) on the other hand, Conventional tillage showed lower bulk density, higher water holding capacity and porosity which results in increasing root depth and yield of maize compared to zero tillage (20). The objective of this research, the effect of different tillage systems on physical soil properties and benefit from conventional tillage to decrese the electrical condectivity for water on soil and plant

\section{MATERIALS AND METHODS}

A field experiment was conducted in Babylon governorate / Almadhateyia district in Iraq, located along (N: $32^{\circ} 25,25^{\prime}$ E: $44^{\circ} 40,030^{\prime}$ ). The soil was loamy texture. A sample was taken to the laboratory to do some physical and chemical tests before conduction the experiment. Examination ways of soil are used in accordance with (18) Table 1 shows these properties. The experiment was carried out to investigate the saline effect of irrigation water of different sources $(\mathrm{w} 1=$ river $-\mathrm{w} 2=$ Drainage - w3=well) water with electrical conductivity $\left(1.3,3.5\right.$ and 6.9) dS. $\mathrm{m}^{-1}$ respectively at stated in the table 1 . Different types of tillage were used: zero tillage (ZT), conventional tillage (CT) and deep tillage (DT), devidly. The land site was dividing into three parts, each part was irrigated with a different type of water. The experimental was performed in RCBD with 3 replicatores. thus, the experimental units are 27 ( 3 water resources $* 3$ tillage types $* 3$ replicators), each unit is of $2 * 2 \mathrm{~m}^{2}$ with a space of $0.75 \mathrm{~m}$. the wheat was cultivated, taking into consideration the addition of the fertilizer recommendations. The watering was carried out depending on the need of soil and plant to the water during the growth period always keep the soil in field capacity. After completing the cultivation and harvesting processes, some measures were conducted to the soil, Bulk density mean weight diameter, hydraulic conductivity, porosity and Penetration Resistance. 
Table 1. some soil properties of the experimental field before harvest

\begin{tabular}{|c|c|c|c|c|c|c|c|c|}
\hline $\begin{array}{l}\text { Property } \\
\text { Unit }\end{array}$ & $\begin{array}{l}\text { EC } \\
\text { ds.m }^{-1}\end{array}$ & pH & 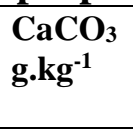 & $\begin{array}{l}\mathrm{CaSO}_{4} \\
\text { g.kg-1 }^{-1}\end{array}$ & $\begin{array}{l}\text { O.M } \\
\text { g.kg-1 }\end{array}$ & $\begin{array}{l}\text { Bulk } \\
\text { density } \\
\text { Mg.m } \\
\end{array}$ & $\begin{array}{l}\text { Particle } \\
\text { density } \\
\text { Mg.m-3 } \\
\end{array}$ & $\begin{array}{l}\text { Hydraulic } \\
\text { conductivity } \\
\text { cm.h }\end{array}$ \\
\hline Value & 2.65 & 7.70 & 229 & 1.80 & 9.80 & 1.41 & 2.65 & 1.70 \\
\hline $\begin{array}{c}\text { Property } \\
\text { Unit }\end{array}$ & $\begin{array}{c}\mathrm{Ca}^{+2} \\
\text { Meq. }^{-1}\end{array}$ & $\begin{array}{c}\mathrm{Mg}^{+2} \\
\text { Meq.l' }_{1}\end{array}$ & $\begin{array}{c}\mathbf{K}^{+} \\
\text {Meq. } .^{-1}\end{array}$ & $\begin{array}{c}\mathrm{Na}^{+} \\
{\mathrm{Meq} . \mathrm{I}^{-1}}^{-1}\end{array}$ & $\begin{array}{c}\mathrm{SO}_{4}^{-2} \\
\text { Meq. }^{-1}\end{array}$ & $\begin{array}{l}\mathrm{HCO}_{3}^{-} \\
{\mathrm{Meq} . \mathrm{I}^{-1}}^{-1}\end{array}$ & $\begin{array}{c}\mathrm{Cl}^{-} \\
\text {Meq. }^{-1}\end{array}$ & Texture \\
\hline Value & 12.10 & 7.80 & 1.00 & 10.20 & 10.90 & 2.50 & 13.30 & Loamy \\
\hline
\end{tabular}

Table 2. water properties of the experimental study

\begin{tabular}{|c|c|c|c|c|c|c|c|c|c|c|}
\hline $\begin{array}{l}\text { Property } \\
\text { Unit }\end{array}$ & $\begin{array}{l}\text { EC } \\
\text { ds.m }{ }^{-1}\end{array}$ & pH & $\begin{array}{l}\mathrm{Ca}^{+2} \\
\text { Meq. }^{\mathrm{I}^{-1}}\end{array}$ & $\begin{array}{l}\mathbf{M g}^{+2} \\
\text { Meq. } \mathbf{I}^{-1}\end{array}$ & $\begin{array}{l}\mathrm{K}^{+} \\
\text {Meq. }^{\mathrm{l}^{1}}\end{array}$ & $\begin{array}{l}\mathrm{Na}^{+} \\
\text {Meq. }^{\mathrm{I}^{-1}}\end{array}$ & $\begin{array}{l}\mathrm{SO}_{4}^{-2} \\
\text { Meq. } \mathrm{I}^{-1}\end{array}$ & $\begin{array}{l}\mathrm{HCO}_{3}^{-} \\
\text {Meq. }^{-1}\end{array}$ & $\begin{array}{l}\mathrm{Cl}^{-} \\
\text {Meq. }^{-1}\end{array}$ & $\begin{array}{l}\text { Water } \\
\text { quality }\end{array}$ \\
\hline River (w1) & 1.3 & 7.45 & 8.1 & 2.8 & 0.30 & 5.1 & 6.3 & 2.1 & 6.2 & C3S1 \\
\hline Drainage (w2) & 3.5 & $\mathbf{7 . 7 5}$ & 15.1 & 10.0 & 1.20 & 14.4 & 12.4 & 3.9 & 22.3 & C4S1 \\
\hline Well (w3) & 6.9 & 7.87 & 38.3 & 19.9 & 0.45 & 23.6 & 34.1 & 7.1 & 40.1 & C4S1 \\
\hline
\end{tabular}

RESULT AND DISCUSSION

Effect of irrigation water quality and tillage treatment on soil physical properties

- bulk density and porosity:

Table 3 show the effect of water quality and tillage treatment on bulk density and porosity. it has been noted that there was a significant effect for the type of irrigation water on bulk density.Bulk density values were $1.40,1.44$ and $1.47 \mathrm{mg} \cdot \mathrm{m}^{-3}$ for $\mathrm{w} 1, \mathrm{w} 2$ and $\mathrm{w} 3$, respectively. It was found that there was a decrease in soil porosity. it was reduced from $47.3 \%$ When irrigating with $\mathrm{W} 1$ to $45.8 \%$ and $44.3 \%$ when irrigated with $\mathrm{W} 2$ and $\mathrm{W} 3$ and respectively. The reason of increase in apparent density and decrease in porosity in salt water irrigation could be attributed to the collapse of small aggregates and deposited in the spaces within the groupings, which led to the formation of semi-compressed layers which in turn leads to increasing the bulk density and decreasing the porosity $(2,7)$ As for the effect of tillage depth, it was found that the bulk density values decreased with increasing tillage depth. while porosity decrease, whose values have increased with increasing depth.Bulk density values were $1.48,1.44$ and $1.38 \mathrm{mg} \cdot \mathrm{m}^{-3}$ for ZT, CT and DT respectively, while porosity values were 44.3 , 45.7 and 47.8 for ZT, CT and DT respectively.The reason for the decline of bulk density when increasing the depth of tillage is attributed to the fact that tillage contributes to the disintegration and fragmentation of soil blocks into small blocks which contributes to increasing Bulk valume, and increasing porosity. Since the relationship between the volume and the bulk density is not contrast, so increasing the size reduces the bulk density value $(17,5,11)$. Some researchers point out that the decrease in bulk density values at conventional tillage compared to other types of tillage is because tillage is breaking the soilsubsurface to produce loose soil. It has been documented that zero tillage gives high penetration resistance compared with other tillage types (1). For the relationship between irrigation water salinity and tillage depth, it has been found that the highest value (1.50) mg. $\mathrm{m}^{-3}$ obtained at ZT and $\mathrm{W} 3$, while the lowest value ( 1.34 ) Mg.m $\mathrm{m}^{-3}$ obtained at DT and $\mathrm{W} 1$.

Table 3. Effect of water quality and tillage systems on bulk density and porosity

\begin{tabular}{|c|c|c|c|c|c|}
\hline Soil property & & W1 & W2 & W3 & Average \\
\hline \multirow{3}{*}{$\begin{array}{l}\text { Bulk density } \\
\text { mg. } \mathrm{m}^{-3}\end{array}$} & ZT & 1.45 & 1.48 & 1.50 & 1.48 \\
\hline & CT & 1.40 & 1.45 & 1.47 & 1.44 \\
\hline & DT & 1.34 & 1.38 & 1.43 & 1.38 \\
\hline \multirow{2}{*}{$\begin{array}{c}\text { Average } \\
\text { L.S.D }\end{array}$} & & 1.40 & 1.44 & 1.47 & \\
\hline & \multicolumn{5}{|c|}{0.30} \\
\hline \multirow{3}{*}{$\begin{array}{c}\text { Porosity } \\
\%\end{array}$} & ZT & 45.3 & 44.2 & 43.4 & 44.3 \\
\hline & CT & 47.2 & 45.3 & 44.5 & 45.7 \\
\hline & DT & 49.4 & 47.9 & 46.0 & 47.8 \\
\hline Average & & 47.3 & 45.8 & 44.7 & \\
\hline L.S.D & & & & & \\
\hline
\end{tabular}

\section{-Mean Weight Diameter (MWD)}

Table 4 state that there a decline in value of mean weight diameter when increasing the irrigation water salinity. It decreased from $0.65 \mathrm{~mm}$ when using $\mathrm{W} 1$ to $0.50,0.27 \mathrm{~mm}$ when using W2 and W3, respectively. This is 
due to the negative role of salts on the accumulation of soil particles that lead to dispersion and deterioration of soil construction (8). As for the effect of the tillage treatment, it was found that the value of mean weight diameter was reduced from $0.50 \mathrm{~mm}$ at ZT to reach $0.49 \mathrm{~mm}$ and $0.44 \mathrm{~mm}$ at the CT and DT, respectively. This is due to the role of

Table 4. Effect of water quality and tillage systems on mean weight diameter

\begin{tabular}{|c|c|c|c|c|c|}
\hline Soil property & & W1 & W2 & W3 & \\
\hline & Zt & $\mathbf{0 . 7 3}$ & $\mathbf{0 . 5 0}$ & $\mathbf{0 . 2 8}$ & $\mathbf{0 . 5 0}$ \\
Mean Weight Diameter (MWD) & Ct & 0.64 & $\mathbf{0 . 5 3}$ & $\mathbf{0 . 3 0}$ & 0.49 \\
mm & Dt & $\mathbf{0 . 5 9}$ & $\mathbf{0 . 4 8}$ & $\mathbf{0 . 2 5}$ & $\mathbf{0 . 4 4}$ \\
L.S.D & & 0.65 & $\mathbf{0 . 5 0}$ & $\mathbf{0 . 2 7}$ & \\
\hline
\end{tabular}

\section{- Penetration Resistance}

Table 5 show the impact of irrigation water quality on the values of penetration resistance. This value increased with the increase of irrigation water salinity, it increased from $377 \mathrm{kba}$ at $\mathrm{W} 1$ to be $403 \mathrm{kpa}$ and $445 \mathrm{kpa}$ at $\mathrm{W} 2$ and $\mathrm{W} 3$, respectively. This is because of the effect of salty water which separates and deposits the soil particles at the spaces making up adhesive material (21). This process will lead to gathering the salts at the surface layer to make a solid shell increasing penetration resistance. Concerning the effect of tillage on the values of penetration resistance, it has been tillage in soil disintegration, leading to a decrease in the mean weight diameter values, (14) In terms of the intersection between the quality of irrigation water and the level of tillage, it was found that the highest level was $0.73 \mathrm{~mm}$ at $\mathrm{Zt}$ and $\mathrm{W} 1$. The lowest MWD value was $0.25 \mathrm{~mm}$ at $\mathrm{Dt}$ and $\mathrm{W} 3$.

Table 5. Effect of water quality and tillage systems on penetration resistance

\begin{tabular}{|c|c|c|c|c|c|}
\hline Soil property & & W1 & W2 & W3 & \\
\hline Penetration Resistance & Zt & $\mathbf{4 2 0}$ & $\mathbf{4 4 5}$ & $\mathbf{4 7 8}$ & $\mathbf{4 4 7 . 7}$ \\
kpa & Ct & 371 & 395 & 423 & 396.3 \\
& Dt & 340 & 370 & 405 & 371.7 \\
L.S.D & & 377 & $\mathbf{4 0 3 . 3}$ & $\mathbf{4 3 5 . 3}$ & \\
\hline
\end{tabular}

\section{- Hydraulic conductivity}

Table 6 shows that hydraulic conductivity, values have been affected by water salinity and tillage systems. And their values were decreased with increasing salinity of irrigation water, values were $\left(5.13,4.26\right.$ and $4.36 \mathrm{~cm} . \mathrm{h}^{-}$ 1 when irrigated by derange and well water respectively, The reason for this is that the salt water is working on the construction of soil structure, which works on low porosity due to found that there is a significant effect at the least $0.05 \%$. The value decreased with the increase of tillage depth, it reached $447.7 \mathrm{kpa}$ at $\mathrm{Zt}$ while it falls to $396.3 \mathrm{kpa}$ and $371.7 \mathrm{kpa}$ at $\mathrm{Ct}$ and $\mathrm{Dt}$, respectively. This is due to the fact the tillage depth has improved some soil physical properties such as increasing the volume humidity content of the soil and improved the drainage conditions and decreased the bulk density $(6,3)$ About the interaction between the quality of irrigation water and level of tillage, the highest value was $478 \mathrm{kpa}$ at $\mathrm{Zt}$ and $\mathrm{W} 3$ while the lowest was $340 \mathrm{kpa}$ at Dt and W1.

\section{Table 6. Effect of water quality and Tillage systems on Penetration Resistance}

\begin{tabular}{|c|c|c|c|c|c|}
\hline Soil property & & W1 & W2 & W3 & \\
\hline Penetration Resistance & Zt & $\mathbf{4 2 0}$ & $\mathbf{4 4 5}$ & $\mathbf{4 7 8}$ & $\mathbf{4 4 7 . 7}$ \\
kpa & Ct & $\mathbf{3 7 1}$ & $\mathbf{3 9 5}$ & $\mathbf{4 2 3}$ & $\mathbf{3 9 6 . 3}$ \\
& Dt & $\mathbf{3 4 0}$ & $\mathbf{3 7 0}$ & $\mathbf{4 0 5}$ & $\mathbf{3 7 1 . 7}$ \\
L.S.D & & 377 & $\mathbf{4 0 3 . 3}$ & $\mathbf{4 3 5 . 3}$ & \\
\hline
\end{tabular}




\section{REFRENCES}

1. Abagandura, G.O., M.Eld-Deen, G.Nasr, and N.M. Moumen, 2017 Influence of tillage practices on soil physical properties and growth and yield of maize in jabal al akhdar, Libya. Open Journal of Soil Science, 7,118132

2. Abdul Moneim, Sinan Nizar. . 2008. Effect of Magnetization of Irrigation Water on Some Physical Properties of Three calcareous and gypsum and Zea mays L. M.S.C Thesis. Department of Soil and Water Sciences. Faculty of Agriculture. University of Baghdad pp:200.

3. Aikins, S. H. M., and J. J. Afuakwa, 2012. Effect of four different tillage practices on soil physical properties under cowpea. Agriculture and Biology Journal of North America, 3(1), 17-24

4. Alam, M., M.Islam, N. Salahin, and M. Hasanuzzaman, 2014. Effect of tillage practices on soil properties and crop productivity in wheat-mungbean-rice cropping system under subtropical climatic conditions. The Scientific World Journal,

5. Alavijeh, H. r., H. A. Chenarbon and B. Zand, 2013. Effect of different tillage methods on soil physical properties and yield of two varieties of forage maize in varamin province. International Journal of Agriculture and Crop Sciences., 1092-1098

6. Almehmdy. SH. M. 2013. Effect of tillage depth and softening on some soil physical properties of potato growth and yield. alAnbar Journal of Agricultural Sciences ،241252.

7. Al-Wazan, F. A. 2009. Effect of irrigation water qualities on some physical characteristics of soil in nenevah province. Journal of Tikrit University For Agriculture Sciences, 486-491

8. AL.Zobae, S. S., and A. H. AL.Sheikhly, 2011. Effect of water irrigation quality and mulching on some soil physical properties under drip irrigation system. The Iraqi Journal of Agricultural Sciences, 33-41

9. Assaffii , I. A. 'A. A. Al-Hadeth and Y. K. Hamza. 2012. The use of organic plants wastes and mineral materials in the treatment of saline water and its application in irrigation. ALAnbar Journal of Agricultural Sciences ،174184
10. Bationo, A., C. L. Bielders, N. Van Duiverbooden, and F. Seyni, 1998. The management of nutrients and water in the West African semi-arid tropics. Management of nutrients and water in rainfed arid and semiarid areas, 29(49): 1026.

11. Elzubeir, A. O. 2014. Influence of tillage systems on soil physical properties. American Journal of Experimental Agriculture, 4(4): 384 12. Emdad, M. R., M. Shahabifar, and H. Fardad. 2006. Effect of different water qualities on soil physical properties. In Proc. Tenth International Water Technology Conference, Alexandria, Egypt pp: 647-652

13. Hassan, D. F., R. J. Mohammed, , A. M. Akol, E. H.Abd, and T. F.Kadhim, 2016. Effect of magnetization of fresh and salt water for irrigation in some of the physical characteristics of the soil and the growth of wheat. International Journal of Innovative Research in Science, Engineering and Technology, 5 (12):20861-20872.

14. Hossein Tabiehzad, Gokhan Cayci,and Kiarash Afshar Pour Rezaeieh. 2017. The effects of tillage methods on soil aggregation and crop yields in a wheat-corn rotation under semi-arid conditions. Solid Earth Discuss.

15. Ji, B., Y. Zhao, X. Mu, K. Liu. and C. Li. 2013. Effects of tillage on soil physical properties and root growth of maize in loam and clay in Central China. plant, soil and environment, 59, 295-302

16. Mace, J . E . and C. Amrhein. 2001. Leaching and reclamation of a soil irrigation with moderate SAR waters. Soil Sci. Soc. Amer. J . 65 (1) :199

17. Osunbitan, J. A., Oyedele, D. J and K. O. Adekalu, 2005. Tillage effects on bulk density, hydraulic conductivity, and strength of a loamy sand soil in southwestern Nigeria. Soil and Tillage Research, 82(1), 57-64

18. Page, A. L. , R . H . Miller and D. R . Keeney.1982.Methods of soil analysis, part (2) $2^{\text {nd }}$.Agronomy - Wisconsin, Madison. Amer. Soc. Agron, Inc. Publisher . No. 631.41 MET 9-2

19. Ruiz-Vera, V. M., and L. Wu. 2006. Influence of sodicity, clay mineralogy, prewetting rate, and their interaction on aggregate stability. Soil Science Society of America Journal, 70(6), 1825-1833 
20. Senjobi, B.A., O.T.Ande, and A.E. Okulaja, 2013. effects of tillage practices on soil properties under maize cultivation on oxic paleustalf in South Western Nigeria. Open Journal of Soil Science,3,163-168.

21. Shainberg, I., and M. J. Singer, 1985. Effect of electrolytic concentration on the hydraulic properties of depositional crust 1 . Soil Science Society of America Journal, 49(5), 1260-1263
22.Shirani, H., M. A.Hajabbasi, M. Afyuni, , and A. Hemmat, 2002. Effects of farmyard manure and tillage systems on soil physical properties and corn yield in central Iran. Soil and tillage research, 68(2), 101-108

23. Tripathi, R. P., I.Kafil, and Ogbazghi, W. 2015. Tillage and irrigation requirements of sorghum (Sorghum bicolor L.) at Hamelmalo, Anseba Region of Eritrea. Open Journal of Soil Science, 5(12), 287

24. Unger, P. W. and D. K. Cassel. 1991. Tillage proportion related to soil and water conservation. Soil and Tillage Res, 19: 363. 